\title{
Effect of Honey in Improving Breast Cancer Treatment and Gene Expression Modulation of MMPs and TIMPs in Triple-Negative Breast Cancer Cells
}

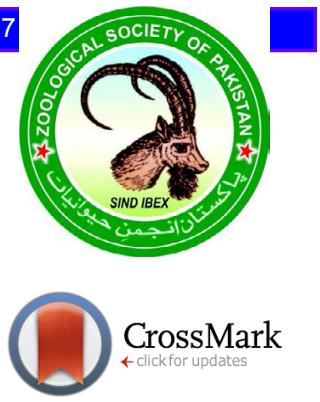

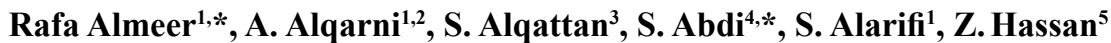 \\ and A. Semlali ${ }^{6}$ \\ ${ }^{1}$ Department of Zoology, College of Science, King Saud University, Riyadh, Saudi \\ Arabia \\ ${ }^{2}$ College of Medicine, Princess Nourah bint Abdulrahman University, Riyadh, Saudi \\ Arabia \\ ${ }^{3}$ King Faisal Specialist Hospital and Research Centre, Riyadh, Saudi Arabia \\ ${ }^{4}$ Department of Biochemistry, College of Science, King Saud University, P.O. Box \\ 22452, Zip Code 11495, Riyadh, Saudi Arabia \\ ${ }^{5}$ Cancer Biology Department, National Cancer Institute, Cairo University, Cairo, Egypt \\ ${ }^{6}$ Genome Research Chair, Department of Biochemistry, College of Science, King Saud \\ University, Riyadh, Saudi Arabia
}

\section{A B S T R A C T}

Breast cancer treatment by chemotherapy or radiotherapy is widely used but has serious side-effects. Thus, honey which is a natural substance has been extensively studied for its anticancer properties. However, its mechanism of action remains unclear. The present study evaluated the effect of two varieties of natural honey (Sidr and Wild) on a human breast adenocarcinoma (MDA-MB-231) cell line. The MDA-MB-231 cell lines were treated with Sidr honey (H1) and Wild honey (H2) for 6, 24, or $48 \mathrm{~h}$ followed by cell morphology evaluation. Cell viability was examined by MTT assay and gene expression of three tissue inhibitors of metalloproteinase (TIMPs) and two matrix metalloproteinase (MMPs) were measured by real-time PCR. All subgroups exhibited altered morphology with accelerated detachment compared to untreated cells. The MTT assay after $48 \mathrm{~h}$ revealed that treatment with $\mathrm{H} 1$ and $\mathrm{H} 2$, reduced cell viability by $48 \%$ and $91 \%$ respectively, compared to that of untreated cells. These results suggest that anticancer effect of Sidr and Wild honey corresponds to their ability to modulate gene expression of MMPs and TIMPs in MDA-MB-231 cell lines. Further investigations are required to understand the molecular mechanism of honey as an anticancer agent.

Article Information
Received 14 April 2018
Revised 30 May 2018
Accepted 13 June 2018
Available online 27 August 2018
Authors' Contribution
RA conceived and designed the project
and wrote the article. AA and SA
performed the experimental work.
ZH analysed the data. SA and AS co-
drafted the manuscript.
Key words
Sidr honey, Wild honey, MMPs,
TIMPs, Triple-negative breast cancer,
Tissue inhibitors of metalloproteinase,
Matrix metalloproteinase.

\section{INTRODUCTION}

$\mathrm{B}$ reast cancer $(\mathrm{BC})$ is a serious health problem worldwide, occurring in both in developed and less developed countries (Jemal et al., 2011). In 2012, it was estimated that more than 1.7 million new cases of breast cancer were diagnosed. Deaths from cancer are projected to increase to over 14.1 million in 2030 (ACS, 2016). There are five groups in breast cancer based on their molecular profiles, including triple-negative breast cancer (TNBC) (Irvin and Carey, 2008), which accounts for approximately $15 \%$ of breast tumors (Lara-Medina et al., 2011). TNBC

\footnotetext{
Corresponding authors: rafaralmeer16@gmail.com; sabdi@ksu.edu.sa 0030-9923/2018/0006-1999 \$ 9.00/0

Copyright 2018 Zoological Society of Pakistan
}

is considered an aggressive but heterogeneous clinical disease for which there is no well-identified mechanism of therapy (Vaz-Luis et al., 2014). However, the standard mechanism of treatment consists of radiation, surgery, and chemotherapy drugs with an anthracyclines basis (i.e., gemcitabine, ixabepilone, vinorelbine, doxorubicin (Doxo), taxanes, and capecitabine). Although, chemotherapy increases the survival rate, it also causes side effects in various body systems (Yu and Jones, 2016).

\footnotetext{
Abbreviations

H1, Sidr honey; H2, Wild honey; TIMPs, tissue inhibitors of metalloproteinase; MMPs, Matrix metalloproteinase; PCR, polymerase chain reaction; MTT (3-(4,5-Dimethylthiazol-2-yl)2,5-Diphenyltetrazolium Bromide); BC, breast cancer; TNBC, triple-negative breast cancer; Doxo, Doxorubicin.
} 
Natural products such as honey have been shown to exhibit potential anticancer effect (Ahmed and Othman, 2017). Honey is composed of various types of sugar, phenolic acids, amino acids, flavonoids, enzymes, and proteins, along with other compounds. Its composition changes according to the flower source and geographical origin (Gheldof et al., 2002). The major factors responsible for the anticancer activity of honey are its phenolic acids (Abubakar et al., 2012). Previous studies suggested several explanations for honey's anticancer effects, but the detailed mechanism remains unclear (Ahmed and Othman, 2013a). Honey from different floral sources may have different effects. The mechanisms suggested for anticancer effect of honey include interference with multiple cell-signaling pathways, such as antiproliferative (Pichichero et al., 2010), inducing apoptosis (Jaganathan and Mandal, 2010), antimutagenic (Saxena et al., 2012), and anti-inflammatory pathways (Hussein et al., 2012).

There are very complex mechanisms and destructive features in cancer, primarily metastasis (Martin et al., 2013). Studies of honey's effects on cancer cells properties are limited. Many metastasis modifiers that may be affected by honey effect have not been examined. Matrix metalloproteinases (MMPs), extracellular-degrading proteases, contribute to metastatic and invasive cancer cells properties; their expression (particularly MMP-9 and MMP-2) is increased in carcinomas (Stamenkovic, 2000) MMPs activity can be specifically inhibited by a group of structurally related, endogenous inhibitors known as tissue inhibitors of metalloproteases (TIMPs) (Al-Olayan et al., 2014). However, some conflicting reports demonstrated that inhibitors or individual proteinases were correlated with the result of surgery in breast cancer patients (Brummer et al., 1999). The effect of honey on MMPs expression and activity has not been widely examined (Porcza et al., 2016). This study examined the role of sidr and wild honey as antiproliferative and cytotoxic agents. Additionally, the mechanisms of its action at the cellular level were examined by evaluated the effect of honey on the expression of MMPs and TIMPs.

\section{MATERIALS AND METHODS}

\section{Cell culture}

Human breast adenocarcinoma (MDA-MB-231) cell lines used in this study were obtained from the Genome Research Chair, King Saud University. Cells were seeded under sterile conditions into RPMI medium (Gibco, Grand Island, NY, USA) containing $10 \%$ fetal bovine serum and $1 \%$ penicillin-streptomycin (UFC Biotech, Riyadh, Saudi Arabia). Cells were cultured in a special flask and the flasks were placed in a $5 \% \mathrm{CO}_{2}$ incubator with $37^{\circ} \mathrm{C}$ humidity. The cells were checked routinely under an inverted microscope to avoid contamination. Every 2-3 days, the media was changed until the cells reached a confluent state.

\section{Honey preparation}

Crude honey (both honeys were purchased from a local market in Riyadh, Saudi Arabia) was initially transfer by sterilized micropipette under sterilized condition in the biological safety cabinet class II then dissolved in culture medium [(RPMI) medium 1640 from $\left(\mathrm{Gibco}^{\circledR}\right.$, UK) supplemented with $1 \%$ fetal bovine serum (FBS) $\left(\right.$ Gibco $\left.^{\circledR}, \mathrm{UK}\right)$ and $1 \%$ of 10000 unit $/ \mathrm{ml}$ penicillin-10000 $\mu \mathrm{g} / \mathrm{ml}$ streptomycin (UFC Biotech, KSA)] at a final concentration of $1 \%(\mathrm{v} / \mathrm{v})$; that means for each $1 \mathrm{ml}$ of medium which needed to coverage the cells of density 3 $\times 10^{5}$ cells / well (in 6 wells culture plate) $10 \mu$ of honey was add and for the density of $9 \times 10^{5}$ cells $/ 25 \mathrm{~cm}^{2}$ culture flask $30 \mu \mathrm{l}$ of honey dissolved in $3 \mathrm{ml}$ of culture medium then added directly on the cells after washing of the cells by PBS Phosphate-Buffered Saline (Gibco ${ }^{\circledR}$, UK).

\section{Treatment}

Cells cultured in 6-wells plates at $3 \times 10^{5}$ cells/well were divided into four groups: Group 1: untreated cells as a negative control, Group 2: cells treated with at $4 \%(v / v)$ concentration of doxorubicin (Doxo) as a positive control, Group 3: cells treated with Sidr honey $(\mathrm{H} 1)$ at $1 \%(v / v)$ concentration, and Group 4: cells treated with Wild honey $(\mathrm{H} 2)$ at $1 \%(v / v)$ concentration. Each group was further divided into three subgroups and cultures were maintained for 6,24 , or $48 \mathrm{~h}$.

\section{Morphological changes}

An inverted microscope (Nikon, Tokyo, Japan) was utilized to monitor the morphological alterations of cells.

\section{Cell viability}

Cell viability in the culture was verified by subjecting confluent cells to the methyl thiazolyl tetrazolium (MTT) assay as described elsewhere (Klettner et al., 2009) with some modifications. Briefly, $100 \mu \mathrm{L}$ of MTT $(5 \mathrm{mg} / \mathrm{mL})$ was added to each well and the plate was incubated for $3 \mathrm{~h}$ at $37{ }^{\circ} \mathrm{C}$ with $5 \% \mathrm{CO}_{2}$ and in a humid atmosphere. Next, the flask was opened slightly for cell aspiration. The tetrazolium crystals were dissolved by viable cells after adding $500 \mu \mathrm{L}$ of isopropanol- $\mathrm{HCl}(0.04 \mathrm{~N})$. A plate reader was used to measure absorbance (X Mark Microplate Spectrophotometer, Bio-Rad, Hercules, CA, USA) at a wavelength of $550 \mathrm{~nm}$. 

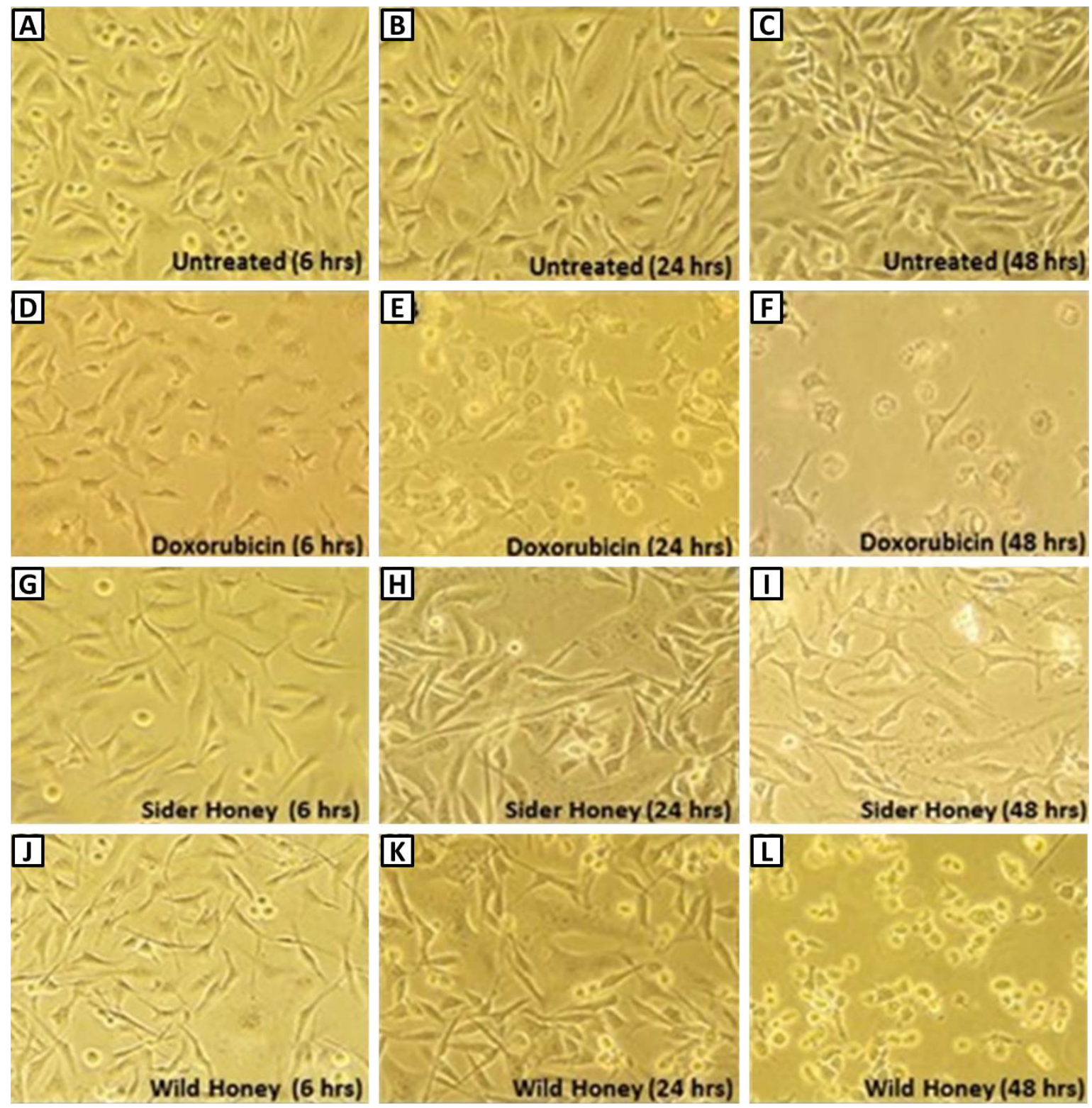

Fig. 1. Cell morphology at 6,24 , and $48 \mathrm{~h}$ of untreated cells (A-C), post-treatment with doxorubicin $4 \%$ (v/v) (D-F), sidr honey $1 \%(\mathrm{v} / \mathrm{v})(\mathrm{G}-\mathrm{I})$ and wild honey $1 \%(\mathrm{v} / \mathrm{v})(\mathrm{J}-\mathrm{L})$.

Table I.- Sequences of primers used in the experiment.

\begin{tabular}{lll}
\hline Gene & Forward primer sequence & Reverse Primer sequence \\
\hline TIMP1 & 5'-ACAACCGCAGCGAGGAGT-3' & 5'-AGGTGACGGGACTGGAAGC-3' \\
TIMP2 & 5'-TTGACCCAGAGTGGAACG-3' & 5'ACCAAAGACGGGAGACGA-3' \\
TIMP4 & 5'-TACCAGGCTCAGCATTAT-3' & 5'-CCACTTGGCACTTCTTATT-3' \\
GAPDH & 5'-AAGGATAATGGCTTACAAC-3' & 5'-TCACTTAGGGCTTCTCAC-3' \\
$M M P-2$ & 5'-TTTCCATTCCGCTTCCAGGGCAC-3' & 5'-TCGCACACCACATCTTTCCGTCACT-3' \\
$M M P-9$ & 5'-CCTGCCAGTTTCCATTCATC-3' & 5'-GCCATTCACGTCGTCCTTAT-3' \\
\hline
\end{tabular}




\section{Gene expression}

As described previously (Semlali et al., 2017), RNA was extracted from harvested cells with a Qiagen kit and RNA purity was measured with a NanoDrop 2000 spectrophotometer (Wilmington, DE, USA). A QuantiTect ${ }^{\circledR}$ Reverse Transcription kit from Qiagen (Hilden, Germany) was used to reverse-transcribe total RNA ( $1 \mu \mathrm{g}$ of each sample) into cDNA. Gene expression of MMPs and TIMPs gene was quantified by reverse transcription PCR. All experiments were conducted in triplicate. Expression levels were determined for $M M P$ 2, MMP-9, TIMP-2, TIMP-1, and TIMP-4 with an endogenous $G A P D H$ as an internal control using a 7500 Real Time PCR system (Applied Biosystems, Foster City, CA, USA) and universal iTaq SYBR green PCR master mix (Bio-Rad). Experiments were performed in triplicate. Primer sequences are listed in Table I. The $25 \mu 1$ RT-PCR reaction components comprising of SYBR Green $(2 x)$, $12.5 \mu \mathrm{l}(1 \mathrm{x})$, Primers; $(\mathrm{F}+\mathrm{R})(10 \mu \mathrm{M}) 0.5 \mu \mathrm{l}$ (10pmole), $\mathrm{H}_{2} \mathrm{O} 7 \mu \mathrm{l}$, CDA $5 \mu 1$ were mixed in 96-well plates. The thermal cycling conditions comprised DNA polymerase activation at $95^{\circ} \mathrm{C}$ for $5 \mathrm{~min}$ followed by 40 cycles each of denaturation at $95^{\circ} \mathrm{C}$ for 30 seconds, Annealing at 55$60^{\circ} \mathrm{C}$ for 45 seconds and extension at $72^{\circ} \mathrm{C}$ for $30 \mathrm{~min}$. After the reactions, the amplification plots were viewed. Baseline and threshold values were adjusted to determine the threshold cycle) CT) for the amplification curves. The results were analyzed using the $2^{\text {-Delta Delta } \mathrm{CT}}$ (Livak and Schmittgen, 2001) relative expression method.

\section{Statistical analysis}

The study involved three different experiments and each experiment was conducted in triplicate, with the results shown as the means \pm SD. The statistical significance of the difference between the control (untreated cell) and test (cell treated by H1, H2, or doxorubicin) values were determined by one-way analysis of variance. An unpaired two-way $t$-test and with a $P$ value $<0.05$ was used to determine significant differences between groups.

\section{RESULTS}

\section{Cell morphology}

MDA-MB-231 cell morphology was examined under an inverted microscope to investigate changes in the cells after treatment with Doxo or honey (H1 and H2) for 6, 24, or 48 h. As shown in Figure 1D-L, the morphology of breast cancer cells treated differed from that of untreated cells. The density of untreated cells (Fig. 1A-C) remained confluent throughout the experimental period. After treatment with Doxo (Fig. 1D-F), most cells showed reduced viability at all three time-points, while treatment with H1 (Fig. 1G-I) resulted in reduced cell density after $48 \mathrm{~h}$ of treatment. A few floating cells were also observed at $48 \mathrm{~h}$. Treatment with H2 (Fig. 1J-L) also reduced cell density after $48 \mathrm{~h}$ of treatment. Many cells were detached from the surface and appeared round at this time point.

\section{MTT assay}

The cytotoxicity of various treatments in MDAMB-231 cells was examined after 6, 24, and $48 \mathrm{~h}$ and compared to that in untreated cells (Fig. 2). Treatment with Doxo significantly reduced cell viability after 24 and $48 \mathrm{~h}$ of treatment (viable cells were $11.7 \%$ and $5.9 \%$, respectively). Treatment with $\mathrm{H} 1$ and $\mathrm{H} 2$ significantly increased cell viability at 6 (viable cells were $106.7 \%$ and $112.6 \%$, respectively) and $24 \mathrm{~h}$ (viable cells were $57.5 \%$ and $115.8 \%$, respectively); while they reduced cell viability after $48 \mathrm{~h}$ (viable cells were $52.6 \%$ and $8.1 \%$, respectively). Thus, Doxo was cytotoxic at 24 and $48 \mathrm{~h}$ treatments, while $\mathrm{H} 1$ and $\mathrm{H} 2$ were cytotoxic only after 48 $\mathrm{h}$ treatment.
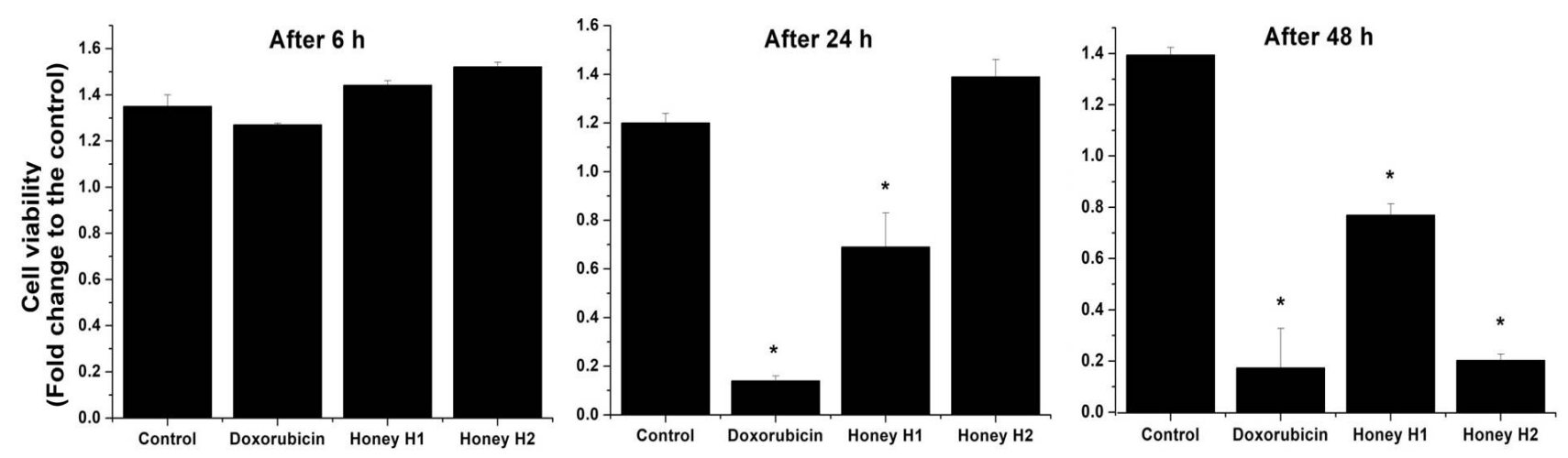

Fig. 2. Cell viability in different subgroups $(6,24$, and $48 \mathrm{~h})$ as estimated by MTT assay. The proliferation of MDA-231 cells was detected by MTT assay after treatment with H1, H2, Doxo and compared to untreated cells. * $p$-value is significant at $<0.05$. 

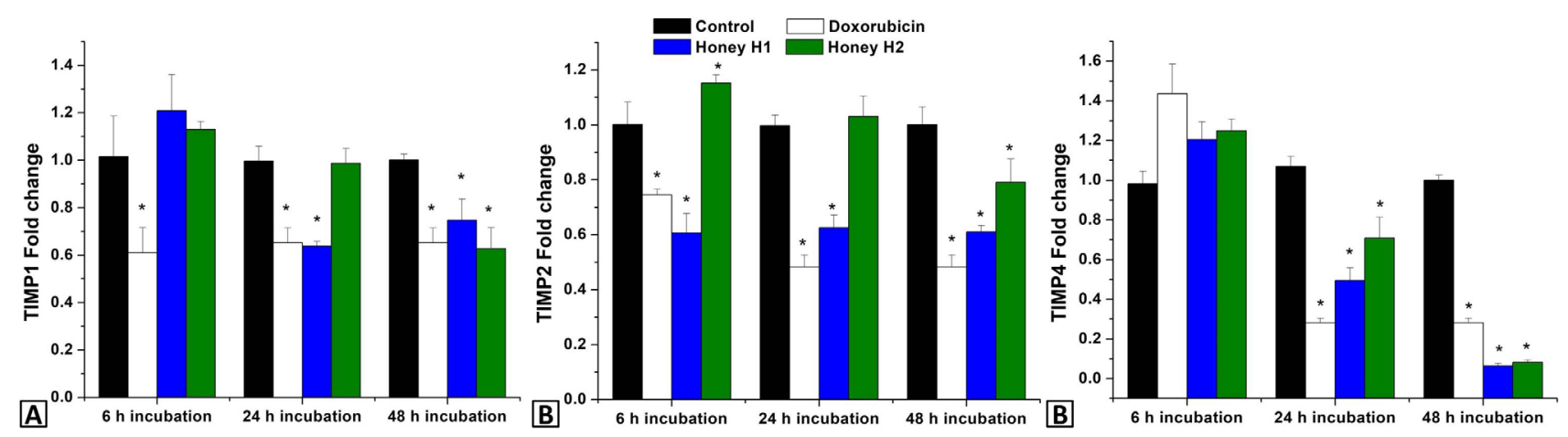

Fig. 3. Expression of TIMPs in (H1, H2 and doxo) treated and untreated breast cancer MDA-231 cells. A, TIMP-1; B, TIMP-2; C, TIMP-4. Columns, mean $(\mathrm{n}=3)$; SD. $* P \leq 0.05$, significant compared to control (untreated cells).

\section{Gene expression profile}

\section{TIMP genes}

As shown in Figure 3A, the expression of TIMP-1 was significantly reduced ( 0.61 -fold) after $6 \mathrm{~h}$ of treatment with Doxo $(p=0.013)$. After $24 \mathrm{~h}$ of incubation, TIMP1 gene expression was reduced both in H1-treated (0.63fold) and Doxo-treated ( 0.65 -fold) cells $(p=0.0003$ and $p=0.001$, respectively). After $48 \mathrm{~h}$ of treatment, TIMP-1 expression was further reduced in $\mathrm{H} 1$-treated $(0.748$-fold) and $\mathrm{H} 2$-treated $(0.628$-fold) cells $(p=0.001)$.

Figure 3B shows TIMP-2 expression levels in various subgroups. Compared to untreated cells, TIMP-2 was significantly downregulated in both Doxo-treated (0.74fold) and $\mathrm{H} 1$-treated ( 0.60 -fold) cells after $6 \mathrm{~h}$ of incubation ( $p=0.003$ and $p=0.002$, respectively). After $24 \mathrm{~h}$ of incubation, TIMP-2 gene expression was further reduced both in H1-treated (0.48-fold) and Doxo-treated (0.62fold) cells $(p<0.001)$. Incubation for $48 \mathrm{~h}$ downregulated TIMP-2 expression both in H1-treated (0.61-fold, $p<$ $0.001)$ and $\mathrm{H} 2$-treated $(0.79$-fold, $p=0.013)$ cells.

In contrast to the expression of TIMP-1 and TIMP-2, the expression of TIMP-4 was non-significantly $(p<0.05)$ changed (Fig. 3C) after $6 \mathrm{~h}$ treatment with $\mathrm{H} 1, \mathrm{H} 2$, and Doxo (1.20-, 1.24-, and 1.43-fold, respectively). However, $24 \mathrm{~h}$ of treatment with Doxo and H1 downregulated the expression of TIMP-4 to 0.28 - and 0.49 -fold ( $p=$ 0.001 and $p=0.019$ ), respectively. Incubation for $48 \mathrm{~h}$ downregulated TIMP-4 expression both in H1-treated (0.064-fold, $p<0.001)$ and H2-treated (0.081-fold, $p<$ $0.001)$ cells (Fig. $3 \mathrm{C}$ ).

\section{MMP genes}

Treatment with $\mathrm{H} 1$ alone for $6 \mathrm{~h}$ significantly downregulated MMP-9 gene expression levels (0.003fold, $p<0.001)$. After $24 \mathrm{~h}$ of treatment with Doxo alone, $M M P-9$ expression was reduced by 0.23 -fold $(p=0.01)$. After $48 \mathrm{~h}$ of incubation, expression of $M M P-9$ was significantly reduced by 0.46 - and 0.63 -fold in response to $\mathrm{H} 1$ and $\mathrm{H} 2$ honey treatment $(p=0.002, p=0.013)$, respectively (Fig. 4A).

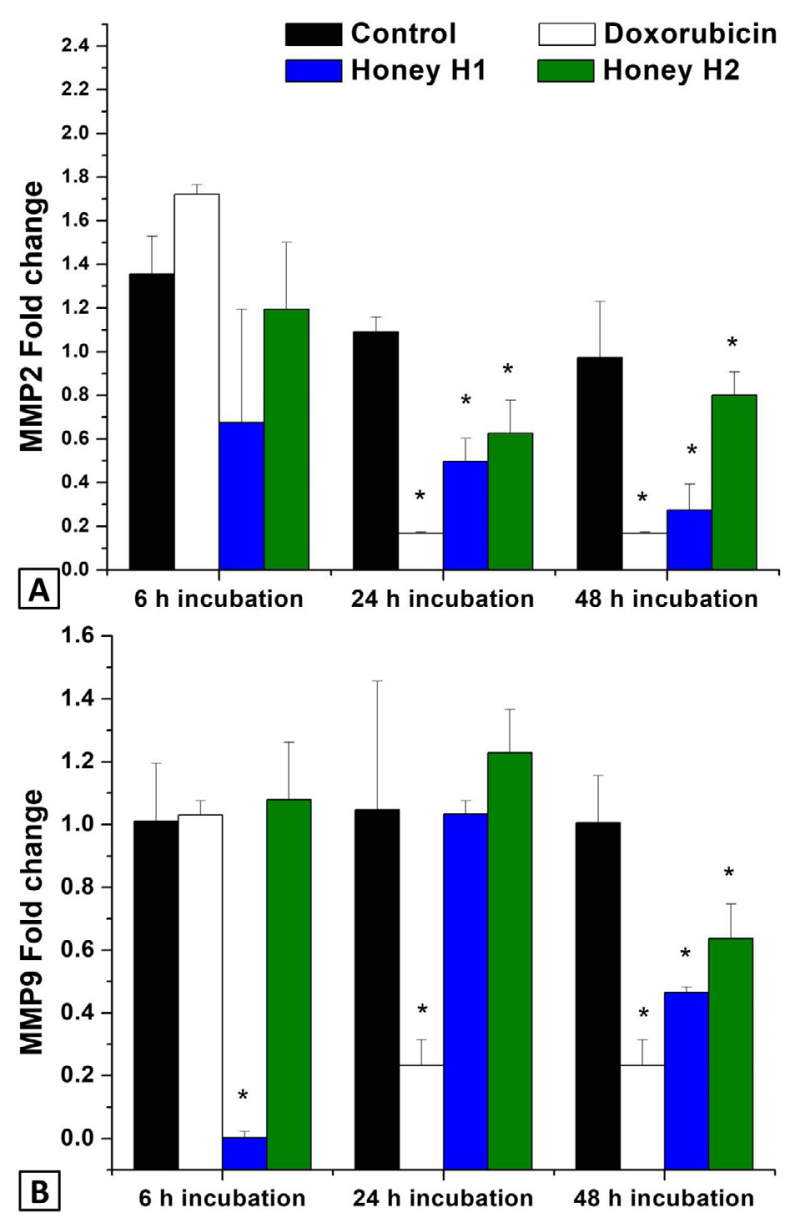

Fig. 4. Expression of $M M P S$ in (H1, $\mathrm{H} 2$ and Doxo) treated and untreated breast cancer MDA-231 cells. A, MMP-9; $\mathrm{B}, M M P-2$ gene. Columns, mean $(\mathrm{n}=3)$; SD. ${ }^{*} p \leq 0.05$, significantly compared to untreated control. 
$M M P$-2 gene expression levels (Fig. 4B) showed no significant difference at $6 \mathrm{~h}$ post-treatment for all samples. A significant reduction in gene expression was observed after 24 and $48 \mathrm{~h}$ incubation with $\mathrm{H} 1$, which reached the lowest expression level of 0.27 -fold at $48 \mathrm{~h}$ incubation $(p=0.007)$. In $\mathrm{H} 2$-treated cells, $M M P-2$ expression was significantly reduced to 0.62 -fold after $24 \mathrm{~h}$ treatment $(p=$ $0.015)$. Doxo reduced the expression of $M M P-2$ to 0.168 fold after $24 \mathrm{~h}$ incubation $(p=0.001)$.

\section{DISCUSSION}

Cancer is one of the most common cause of death worldwide and its prevention and treatment are challenging. TNBCs are the most aggressive type of breast cancer. Unlike the positive hormone receptor breast cancer tumors or HER-2/Neu amplified breast cancer tumors, TNBC does not respond to hormonal therapy or therapies targeting HER2 receptors. The present treatments for TNBCs are surgery, chemotherapy, and radiotherapy, which cause adverse side effects in the patient's body (Chavez et al., 2010).

Therefore, a large number of scientific studies have focused on natural food-derived products with minimum side effects for treating breast cancer patients. Previous studies showed that honey contains several bioactive compounds and exerts various anticancer effects via diverse mechanisms affecting different stages of cancer development and progression (Erejuwa et al., 2014). The mechanisms suggested for the anticancer effects of honey include its antiproliferative, apoptotic, antioxidant, antitumor necrosis factor, estrogenic and immunomodulatory activities, and anti-inflammatory effects (Ahmed and Othman, 2013a). However, the full mechanism remains unclear (Roy et al., 2009). The antioxidant and anti-inflammatory action of honey is mainly related to its phenolic constituents (Ahmed and Othman, 2013b). The highest phenolic contents have been found in manuka honey and tualang honey, while the lowest identified phenolic contents were in 2 types of honey, acacia and gelam. The phenolic content of honey is affected by numerous factors, including the type of flower utilized as the source of honey along with geographical origin (Sergiel et al., 2014). Honey of various floral resources may have different results. Thus, further intensive studies are required to provide a more comprehensive understanding of the positive impact of using honey for treating various types of cancer. Traditionally, Sidr honey has been clinically used to treat infected wounds, as medication in traditional medicine, and as an antibacterial agent. Sidr honey is mono-floral and is produced by feeding of bees from Sidr tree (Ziziphus spina-christi) only. A toxicity study of Sidr honey revealed that it is safe to consume and there is no threat of toxicity at high concentrations. This type of honey possesses potent anti-inflammatory, antipyretic, and analgesic properties. These properties may originate from the phytochemicals present in the honey (Mijanur et al., 2014). Wild honey is polyclonal, but is unique in that it is not subjected to heat processing before it is sold, leaving most bio-active compounds intact.

The present study investigated the effect of two varieties of honey (Sidr and Wild honey) on an MDAMB-231 cell line (considered as TNBCs) on the cell morphology, proliferation, and MMPs and TIMPs gene expression.

We confirmed that treatment with $\mathrm{H} 1$ and $\mathrm{H} 2$ changed the cell morphology. The changes in H2- and H1-treated cells were most clearly observed at $48 \mathrm{~h}$ post-treatment. The cells had detached from the surface, floated, and tended to be round. Because rounding, shrinkage, membrane blebbing, and losing contact with adjacent cells are typical apoptotic features (Elmore, 2007); both the varieties of honey selected in the current study have the potential to induce apoptosis in TNBC cells after $48 \mathrm{~h}$ of treatment.

The results of the MTT assay emphasize the cytotoxic effect of $\mathrm{H} 1$ and $\mathrm{H} 2$ on the MDA-MB-231 cell line. Although less effective than Doxo in killing the cancer cells, both $\mathrm{H} 1$ and $\mathrm{H} 2$ showed considerable cytotoxicity after $48 \mathrm{~h}$ of treatment. Our results support those of previous studies showing a cytotoxicity effect against human breast cancer cell lines by Tualang (Fauzi et al., 2011) and Thyme (Tsiapara et al., 2009) honey. In contrast to these studies, Tsiapara et al. (2009) showed a stimulatory effect of fir honey on breast cancer cell line proliferation. This may be because different varieties of honey contain different nutrient (minerals, amino acids, and glucose), hydrogen peroxide, and phenolic constituent contents (van der Woude et al., 2003). In the present study, $\mathrm{H} 2$ was found to be more cytotoxic than $\mathrm{H} 1$.

Another unclear aspect that may impact the results of in vitro studies is the effects of sugars on cell proliferation. Glucose is the favored nutrient of cancer cells. Sugar present in honey has been suggested to have mutagenic as well as antimutagenic effects. A review by Porcza et al. (2016) described the impact of honey on the viability of prostate, colon, breast, and various types of brain tumor cell lines. They demonstrated that only in some cell lines, the effect of honey could overcome the impact of sugars. This may be because of the phenolic content of honey and/ or metabolism of sugars, as well as the number of glucose transporters expressed by cancer cells (Medina and Owen, 2002). In the present study, treatment with both $\mathrm{H} 1$ and $\mathrm{H} 2$ for $6-24 \mathrm{~h}$ increased the viability of MDA-MB-231 
cells; however, prolonging the treatment to $48 \mathrm{~h}$ resulted in cytotoxic effects.

Matrix metalloproteinases are vital in the invasive and metastatic properties of cancer cells, and their expression (particularly MMP-2 and MMP-9) is promoted in a range of carcinomas (Deryugina and Quigley, 2006). MMP-9 is one of 70 genes in the Rosetta poor prognosis signature for breast cancer patients (van't Veer et al., 2002). These statistics indicate that variances in MMPs expression can precede and increase the potential of developing breast cancer. The effect of honey on MMPs has not been studied extensively (Roy et al., 2009). This is the first study to evaluate the effect of Sidr and Wild honey on gene expression of MMPs and TIMPs in MDA-MB-231 cell lines. We found that both varieties of honey could modulate the expression of $M M P-9$ and $M M P-2$.

Caffeic acid (CA) is a common phenolic compound found in various natural sources such as honey, fruits, herbs, and vegetables. Chung et al. (2004) established the mechanism of the anti-cancer effects of CA. They found that both CA and its derivative CA phenethyl ester inhibit the enzymatic action of MMP9.

TIMPs are essential anticancer molecules (Shimoda et al., 2014). TIMP2 has evolved to exhibit broad inhibition effects towards many MMPs (Radisky and Radisky, 2015). Reports that correlate individual proteinases or inhibitors with the results in patients with breast cancer have shown conflicting results. For example, in situ hybridization revealed a positive relation between TIMP-1 and TIMP-2 expression and tumor grade (Porcza et al., 2016). Another study showed that $M M P-1$ mRNA expression was mainly correlated with the phase of invasion of breast tumors (Benson et al., 2013). In contrast, this relationship has not been reported in most studies (Baker et al., 2002). In many cases, increased expression of MMPs activity and increased expression of one or more TIMPs occurred at the same time. This is likely a defensive mechanism in the body, that is eventually overcome by the tumor (Brown, 1998). In the present study, although TIMP-1 and TIMP2 were downregulated by both $\mathrm{H} 1$ and $\mathrm{H} 2$, TIMP-4 expression was upregulated after $6 \mathrm{~h}$ treatment. Increasing evidence shows that TIMPs can modulate crucial pathways independent of metalloproteinase inhibition (Sun, 2010). These findings suggest that the mechanism of anticancer activity possessed by honey may occur through modulation of gene expression of MMPs and TIMPs.

The results of the present study suggest that honey has anticancer effects and is promising as an adjunct to conventional cancer therapy with minimum side effects. The anticancer activity of honey may be related to its ability to modulate the expression of MMPs and TIMPs. Additional studies are required to test of the effects of using honey at the molecular level and improve our understanding of the positive effects of honey in relation to cancer therapy.

\section{ACKNOWLEDGMENTS}

The authors would like to extend their sincere appreciation to the Deanship of Scientific Research at King Saud University for its funding of this research through the research Group Project no. RGP-180.

\section{Statement of conflicts of interest}

The authors declare that they have no conflict of interests.

\section{REFERENCES}

Abubakar, M.B., Abdullah, W.Z., Sulaiman, S.A. and Suen, A.B., 2012. A review of molecular mechanisms of the anti-leukemic effects of phenolic compounds in honey. Int. J. mol. Sci., 13: 1505415073. https://doi.org/10.3390/ijms 131115054

ACS, 2016. Cancer facts and figures 2016. American Cancer Society, Atlanta. https://www.cancer.org/ content/dam/cancer-org/research/cancer-facts-andstatistics/annual-cancer-facts-and-figures/2016/ cancer-facts-and-figures-2016.pdf

Ahmed, S. and Othman, N.H., 2013a. Honey as a potential natural anticancer agent: A review of its mechanisms. Evidence-Based Compl. Altern. Med., 2013: 7 .

Ahmed, S. and Othman, N.H., 2013b. Review of the medicinal effects of tualang honey and a comparison with manuka honey. Malaysian J. med. Sci., 20: 6-13.

Ahmed, S. and Othman, N.H., 2017. The anti-cancer effects of Tualang honey in modulating breast carcinogenesis: an experimental animal study. BMC Compl. Altern. Med., 17: 208. https://doi. org/10.1186/s12906-017-1721-4

Al-Olayan, E.M., El-Khadragy, M.F., Aref, A.M., Othman, M.S., Kassab, R.B. and Abdel-Moneim, A.E., 2014. The potential protective effect of Physalis peruviana L. against carbon tetrachlorideinduced hepatotoxicity in rats is mediated by suppression of oxidative stress and downregulation of MMP-9 expression. Oxid. Med. Cell. Longev, 2014:381413. https://doi.org/10.1155/2014/381413

Baker, E.A., Stephenson, T.J., Reed, M.W. and Brown, N.J., 2002. Expression of proteinases and inhibitors in human breast cancer progression and survival. Mol. Pathol., 55: 300-304. https://doi.org/10.1136/ 
$\mathrm{mp} .55 .5 .300$

Benson, C.S., Babu, S.D., Radhakrishna, S., Selvamurugan, N. and Ravi-Sankar, B., 2013. Expression of matrix metalloproteinases in human breast cancer tissues. Dis. Markers, 34: 395-405. https://doi.org/10.1155/2013/420914

Brown, P.D., 1998. Matrix metalloproteinase inhibitors. Breast Cancer Res. Treat., 52: 125-136. https://doi. org/10.1023/A:1006119319695

Brummer, O., Athar, S., Riethdorf, L., Loning, T. and Herbst, H., 1999. Matrix-metalloproteinases 1,2 , and 3 and their tissue inhibitors 1 and 2 in benign and malignant breast lesions: An in situ hybridization study. Virchows Arch., 435: 566-573. https://doi.org/10.1007/s004280050442

Chavez, K.J., Garimella, S.V. and Lipkowitz, S., 2010. Triple negative breast cancer cell lines: One tool in the search for better treatment of triple negative breast cancer. Breast Dis., 32: 35-48. https://doi. org/10.3233/BD-2010-0307

Chung, T.W., Moon, S.K., Chang, Y.C., Ko, J.H., Lee, Y.C., Cho, G., Kim, S.H., Kim, J.G. and Kim, C.H., 2004. Novel and therapeutic effect of caffeic acid and caffeic acid phenyl ester on hepatocarcinoma cells: Complete regression of hepatoma growth and metastasis by dual mechanism. FASEB J., 18: 16701681. https://doi.org/10.1096/fj.04-2126com

Deryugina, E.I. and Quigley, J.P., 2006. Matrix metalloproteinases and tumor metastasis. Cancer Metastasis Rev., 25: 9-34. https://doi.org/10.1007/ s10555-006-7886-9

Elmore, S., 2007. Apoptosis: A review of programmed cell death. Toxicol. Pathol., 35: 495-516. https:// doi.org/10.1080/01926230701320337

Erejuwa, O.O., Sulaiman, S.A. and Wahab, M.S., 2014. Effects of honey and its mechanisms of action on the development and progression of cancer. Molecules, 19: 2497-2522. https://doi.org/10.3390/ molecules 19022497

Fauzi, A.N., Norazmi, M.N. and Yaacob, N.S., 2011. Tualang honey induces apoptosis and disrupts the mitochondrial membrane potential of human breast and cervical cancer cell lines. Fd. Chem. Toxicol., 49: 871-878. https://doi.org/10.1016/j. fct.2010.12.010

Gheldof, N., Wang, X.H. and Engeseth, N.J., 2002. Identification and quantification of antioxidant components of honeys from various floral sources. J. Agric. Fd. Chem., 50: 5870-5877. https://doi. org $/ 10.1021 / \mathrm{jf0} 256135$

Hussein, S.Z., Yusoff, M.K., Makpol, S. and Yusof, M.Y.A., 2012. Gelam honey inhibits the production of proinflammatory, Mediators NO, TNF-\&\#x3b1, and IL-6 in Carrageenan-induced acute paw edema in rats. Evidence-Based Compl. Altern. Med., 2012: 13.

Irvin, Jr. W.J. and Carey, L.A., 2008. What is triplenegative breast cancer? Eur. J. Cancer, 44: 27992805. https://doi.org/10.1016/j.ejca.2008.09.034

Jaganathan, S.K. and Mandal, M., 2010. Involvement of non-protein thiols, mitochondrial dysfunction, reactive oxygen species and p53 in honey-induced apoptosis. Invest. New Drugs, 28: 624-633. https:// doi.org/10.1007/s10637-009-9302-0

Jemal, A., Bray, F., Center, M.M., Ferlay, J., Ward, E. and Forman, D., 2011. Global cancer statistics. $C A$ Cancer J. Clin., 61: 69-90. https://doi.org/10.3322/ caac. 20107

Klettner, A.K., Kruse, M.L., Meyer, T., Wesch, D., Kabelitz, D. and Roider, J., 2009. Different properties of VEGF-antagonists: Bevacizumab but not Ranibizumab accumulates in RPE cells. Graefes Arch. Clin. Exp. Ophthalmol., 247: 16011608. https://doi.org/10.1007/s00417-009-1136-0

Lara-Medina, F., Perez-Sanchez, V., Saavedra-Perez, D., Blake-Cerda, M., Arce, C., Motola-Kuba, D., Villarreal-Garza, C., Gonzalez-Angulo, A.M., Bargallo, E., Aguilar, J.L., Mohar, A. and Arrieta, O., 2011. Triple-negative breast cancer in Hispanic patients: High prevalence, poor prognosis, and association with menopausal status, body mass index, and parity. Cancer, 117: 3658-3669. https:// doi.org/10.1002/cncr.25961

Livak, K.J. and Schmittgen, T.D., 2001. Analysis of relative gene expression data using real-time quantitative PCR and the 2(-Delta Delta $\mathrm{C}(\mathrm{T})$ ) method. Methods, 25: 402-408. https://doi. org/10.1006/meth.2001.1262

Martin, T.A., Ye, L., Sanders, A.J., Lane, J. and Jiang W.G., 2013. Cancer invasion and metastasis: Molecular and cellular perspective. In: Madame Curie bioscience database. Landes Bioscience, Austin, TX. https://www.ncbi.nlm.nih.gov/books/ NBK164700/

Medina, R.A. and Owen, G.I., 2002. Glucose transporters: Expression, regulation and cancer. Biol. Res., 35: 9-26. https://doi.org/10.4067/S071697602002000100004

Mijanur-Rahman, M., Gan, S.H. and Khalil, M.I., 2014. Neurological effects of honey: Current and future prospects. Evidance-Based Compl. Altern. Med., 2014: 958721.

Pichichero, E., Cicconi, R., Mattei, M., Muzi, M.G. and Canini, A., 2010. Acacia honey and chrysin reduce 
proliferation of melanoma cells through alterations in cell cycle progression. Int. J. Oncol., 37: 973981.

Porcza, L.M., Simms, C. and Chopra, M., 2016. Honey and cancer: Current status and future directions. Diseases, 4: E30.

Radisky, E.S. and Radisky, D.C., 2015. Matrix metalloproteinases as breast cancer drivers and therapeutic targets. Front. Biosci., 20: 1144-1163. https://doi.org/10.2741/4364

Roy, R., Yang, J. and Moses, M.A., 2009. Matrix metalloproteinases as novel biomarkers and potential therapeutic targets in human cancer. J. clin. Oncol., 27: 5287-5297. https://doi.org/10.1200/ JCO.2009.23.5556

Saxena, S., Gautam, S., Maru, G., Kawle, D. and Sharma, A., 2012. Suppression of error prone pathway is responsible for antimutagenic activity of honey. Fd. Chem. Toxicol., 50: 625-633. https:// doi.org/10.1016/j.fct.2012.01.003

Semlali, A., Jalouli, M., Parine, N.R., Al-Amri, A., Arafah, M., Al-Naeem, A., Abdullah, A.S., Rouabhia, M. and Alanazi, M.S., 2017. Toll-like receptor 4 as a predictor of clinical outcomes of estrogen receptor-negative breast cancer in Saudi women. Onco Targets Ther., 10: 1207-1216. https://doi.org/10.2147/OTT.S112165

Sergiel, I., Pohl, P. and Biesaga, M., 2014. Characterisation of honeys according to their content of phenolic compounds using high performance liquid chromatography/tandem mass spectrometry. Fd. Chem., 145: 404-408. https://doi. org/10.1016/j.foodchem.2013.08.068

Shimoda, M., Principe, S., Jackson, H.W., Luga, V., Fang, H., Molyneux, S.D., Shao, Y.W., Aiken, A., Waterhouse, P.D., Karamboulas, C., Hess, F.M., Ohtsuka, T., Okada, Y., Ailles, L., Ludwig, A., Wrana, J.L., Kislinger, T. and Khokha, R., 2014. Loss of the Timp gene family is sufficient for the acquisition of the CAF-like cell state. Nat. Cell Biol., 16: 889-901. https://doi.org/10.1038/ncb3021

Stamenkovic, I., 2000. Matrix metalloproteinases in tumor invasion and metastasis. Semin. Cancer Biol., 10: 415-433. https://doi.org/10.1006/ scbi.2000.0379

Sun, J., 2010. Matrix metalloproteinases and tissue inhibitor of metalloproteinases are essential for the inflammatory response in cancer cells. $J$. Signal Transduct., 2010: 985132. https://doi. org/10.1155/2010/985132

Tsiapara, A.V., Jaakkola, M., Chinou, I., Graikou, K., Tolonen, T., Virtanen, V. and Moutsatsou, P., 2009. Bioactivity of Greek honey extracts on breast cancer (MCF-7), prostate cancer (PC-3) and endometrial cancer (Ishikawa) cells: Profile analysis of extracts. Fd. Chem., 116: 702-708. https://doi.org/10.1016/j. foodchem.2009.03.024

van der Woude, H., Gliszczynska-Swiglo, A., Struijs, K., Smeets, A., Alink, G.M. and Rietjens, I.M., 2003. Biphasic modulation of cell proliferation by quercetin at concentrations physiologically relevant in humans. Cancer Lett., 200: 41-47. https://doi. org/10.1016/S0304-3835(03)00412-9

van't Veer, L.J., Dai, H., van de Vijver, M.J., He, Y.D., Hart, A.A.M., Mao, M., Peterse, H.L., van der Kooy, K., Marton, M.J., Witteveen, A.T., Schreiber, G.J., Kerkhoven, R.M., Roberts, C., Linsley, P.S., Bernards, R. and Friend, S.H., 2002. Gene expression profiling predicts clinical outcome of breast cancer. Nature, 415: 530. https://doi. org/10.1038/415530a

Vaz-Luis, I., Ottesen, R.A., Hughes, M.E., Mamet, R., Burstein, H.J., Edge, S.B., Gonzalez-Angulo, A.M., Moy, B., Rugo, H.S., Theriault, R.L., Weeks, J.C., Winer, E.P. and Lin, N.U., 2014. Outcomes by tumor subtype and treatment pattern in women with small, node-negative breast cancer: A multiinstitutional study. J. clin. Oncol., 32: 2142-2150. https://doi.org/10.1200/JCO.2013.53.1608

Yu, A.F. and Jones, L.W., 2016. Breast cancer treatmentassociated cardiovascular toxicity and effects of exercise countermeasures. Cardio-Oncology, 2: 1. https://doi.org/10.1186/s40959-016-0011-5 